Original Research Article

\title{
Efficacy and safety of panchgavya GHRIT along with flunarizine in prophylaxis for migraine patients: a comparitive study
}

\author{
Mohit Trivedi $^{1}$, Vikash Dixit ${ }^{1}$, Syed Esam Mahmood $^{2} *$, Sunil Kumar Mishra ${ }^{3}$, S. S. Keshari ${ }^{1}$
}

\author{
${ }^{1}$ Department of Pharmacology, \\ T.S. MISRA Medical College \\ and Hospital, Lucknow, Uttar \\ Pradesh, India \\ ${ }^{2}$ Department of Community \\ Medicine, Government Medical \\ College, Banda, Uttar Pradesh, \\ India \\ ${ }^{3}$ Ayurvedic Consultant, \\ King George's Medical \\ University, Lucknow, Uttar \\ Pradesh, India
}

Received: 02 February 2017 Accepted: 01 March 2017

\section{*Correspondence to:}

Dr. Syed Esam Mahmood, Email: semahmood@gmail.com

Copyright: (C) the author(s), publisher and licensee Medip Academy. This is an openaccess article distributed under the terms of the Creative Commons Attribution NonCommercial License, which permits unrestricted noncommercial use, distribution, and reproduction in any medium, provided the original work is properly cited.

\begin{abstract}
Background: Propranolol and flunarizine have proven to be useful tools in migraine prophylaxis. This trial aims the comparison of the efficacy of flunarizine, flunarizine and placebo and flunarizine and panchgavya ghrit in migraine prophylaxis.

Methods: The present study was a prospective, randomized, open-label, blinded-endpoint trial. Patients with chronic migraine were randomized (1:1:1) to flunarizine and flunarizine and placebo and flunarizine and panchgavya ghrit in three treatment groups. The study was carried out in outdoor patients in the department of Psychiatry, T.S. Mishra Medical College and Hospital, Lucknow and K.G.M.U, Ayush Department, Lucknow after clearance from Institutional Ethical Committee. Data was analysed using SPSS software.

Results: The prevalence of migraine was found to be higher in the age group greater than 30 years and females. Overall there was more reduction in CGI scores in flunarizine with panchgavya ghrit and the other two groups equally at the end of 4, 68 and 10 weeks. Decrease in MIDAS score was observed after the therapy. Clinical Global Impression rating scale employed revealed that to start with subjects scored 7 which stands for pathology interfering in many life functions which reduced drastically in Group C as compared to Group B and Group A in descending order. Pain scales namely VAS (visual analogue scale), NPRS (Numeric Pain Rating Scale), VRS (verbal rating scale) when employed denoted there was decreased migraine frequency, decreased perception of pain, less intake of abortive medication consumed by subjects implying there were reduction in number of migraine days and there was decrease in the abortive medications taken for the same. Group $\mathrm{C}$ scored better on pain scales followed by Group B and Group A. Lower proportion of individuals in group C had Behavioural Toxicity and Neurological Side effects as compared to Group A and $\mathrm{B}$.

Conclusions: Panch gavya ghrit when administered along with flunarizine was more efficacious and safe when compared with other two groups. However large multicentric RCTs of long duration and involving more number of subjects are required to ascertain these facts.
\end{abstract}

Keywords: Flunarizine, Migraine, Panch gavya ghrit

\section{INTRODUCTION}

Migraine is a widespread, chronic and intermittently disabling disorder characterized by recurrent headaches with or without aura. ${ }^{1}$ The prevalence of migraine is about $6-8 \%$ in men and $12-15 \%$ in women as per the conducted studies. Approximately 3000 migraine attacks occur every day for each million of the general population which impress upon the incidence and prevalence of migraine. ${ }^{2}$ The rate of migraine varies globally, and more so with the data available in many countries at present, recent anecdotal evidence suggests higher rates in certain places like India. ${ }^{3}$ Recurrent migraines can be disabling: the cost of missed workdays and impaired performance associated with migraines in the United States totals around $\$ 13$ billion each year. ${ }^{4,5}$ Preventive therapy, which can reduce the frequency of migraines by 50 percent or more, is used by less than one half of persons with migraine headache. ${ }^{6}$ In Ayuveda Arddhavabhedaka - a comparable clinical condition of 
migraine is a commonly occurring vascular headache presenting with pain on one half of the head as cardinal feature. It is described as a separate clinical entity in the classics of Charaka and Susruta while Vagbhata included this condition in the classification of vataja-siroroga. Pain in one half of the head may also appear as a symptom in various conditions viz. anyatovata (netraroga), vata-paryayam (netraroga) and ardditavata (vataroga). According to Ayurveda, action of a drug is based on its guna, veerya, vipaaka and prabhaava. These as themselves or as combinations determine the status of drug action in the body. Fate of the drug always depends on rasapancaka and it goes in line with modern pharmacodynamics. ${ }^{7}$ Besides that the drug action also depends the action of agni on that particular drug. Most of the Ayurvedic drugs act only after absorption and are said to have systemic or general action. Many a time, the term 'action' and 'effect' of a drug are used as synonyms. Many a drug has been mentioned in Ayurvedic psychiatry. Panchagavya gritha (PGG) is mentioned in Apasmara chikitsa. It is one of the commonly used yogas not only for apasmara, but also many other psychiatric conditions including OCD, Migraine Depression and types of Schizophrenia in the form of oral route of drug intake and nasya karma. The combination contains 5 ingredients.

Gos'akr't (Cow dung), Godadhi (Curd), Goksheera (Milk), Gomootra (Cow's urine) and Goghr'ta (Ghee). ${ }^{8}$ All the drugs are taken in equal quantities and the gritha is prepared as per the common preparatory techniques regarding gritha. ${ }^{9}$ Literature revealed that cow ghee, cow milk and cow urine possesses intellect and memory enhancing, rejuvenating and aphrodisiac activities. ${ }^{10-12}$ Cow dung juice has antibacterial and cow curd has aphrodisiac activity. ${ }^{13,14}$ Similarly various researches are reported on single cow products for their effects on CNS. Thus combination of these products may show cumulative desired effect of PGG on cognition i.e. improvement of learning and memory.

Previously PGG has been assessed for anticonvulsant, hepatoprotective and antiepileptic activities; however no work has been carried out on assessment of anti migraine activity of PGG. Sometimes, if migrainous headaches are recurring twice a month or more, a prophylactic treatment is required. ${ }^{15-17}$ There is a variety of medication usually employed in the migraine prophylaxis, a hint that none is entirely effective. Moreover, usually there are patients who do not respond to one or more prophylactic drugs. Besides, there are individual differences in the responsiveness to different prophylactic agents and even sometimes, an inability to sustain an initial good response to a particular agent. Such facts may be arguments for the concomitant use of two modalities of drugs in migraine prophylaxis. Propranolol and flunarizine have proven to be useful tools in migraine prophylaxis. ${ }^{18-21}$ This trial aims the comparison of the efficacy of flunarizine, flunarizine and placebo and flunarizine and panchgavya ghrit in migraine prophylaxis.

\section{METHODS}

The present study was a prospective, randomized, openlabel, blinded-endpoint (PROBE) trial. Patients with chronic migraine $(\mathrm{CM})$ were randomized $(1: 1: 1)$ to flunarizine and flunarizine and placebo and flunarizine and panchgavya ghrit (PGG) in three treatment groups. The study was carried out in outdoor patients in the department of Psychiatry, T.S. Mishra Medical College and Hospital, Lucknow and K.G.M.U, Ayush Department, Lucknow after clearance from Institutional Ethical Committee. Psychiatrist had enrolled participants, administered scales and assessed the clinical outcomes. Side effect monitoring was done and by a pharmacologist and a psychiatrist using DOTES scale. Nasya karma of panchgavya ghrit was done and taught to subjects attendant by competent Ayurvedic practitioner in O.P.D setting. The trial was conducted from September 2016 to January 2017. The patients were included in the study after fulfilling the inclusion/ exclusion criteria after obtaining full informed consent as diagnosed in psychiatry OPD of T.S. Mishra Medical College and Hospital. Systematic Random Sampling was applied and concealment was done by envelop method. Statistician had generated allocation sequence and assigned participants to their respective groups. The sample size was 60 .

\section{Inclusion criteria}

Inclusion Criteria was ICHD-IIR criteria for CM (as reported by the patient). Experienced $\geq 7$ days of headache lasting $\geq 30 \mathrm{~min}$ during T0 ( -2 week to 0 week), On $\geq 4$ of these days, subjects were required to have experienced migrainous headache, patients could receive preventive medications (medications for acute attack) other than the medications given during study period, with and without medication overuse, Subject $>10$ years of age, either gender, headache history $>2$ years, willing to follow the dietary restriction, willing to complete daily diary, willing to take the medication Or comply with procedure during the entire study period.

\section{Exclusion criteria}

Tension-type headache, cluster headache, and other primary headaches, secondary headache and other neurological disease, relatively severe systemic diseases (cardiovascular disease, acute infectious disease, hematopathy, endocrinopathy, allergy, and methysis), headache caused by otorhinolaryngology diseases or intracranial pathological changes, oral contraceptives, pregnancy, or lactation period, use of prophylactic migraine medication in the last 3 months, participation in another clinical trial, headache type other than CM, migraine onset after the age of 60 years, previous history of migraine prophylaxis before enrollment, history of hepatic or renal disorder, nephrolithiasis or other severe systemic disease, severe depression. Marked depression, anxiety or psychosis, major medical illness under 
treatment, clotting disorders, more than 2 visits/month for mental healthcare. Use of any other alternative medication during study apart from rescue medication ultracet a combination of tramadol $37.5 \mathrm{mg}$ and acetaminophen $325 \mathrm{mg}$ as and when required.

Primary outcome measures were to assess reduction of total number of migraine days, quality of life and comparison of side effects in three groups Secondary outcome measures were to assess the disability associated with migraine, reduction of number of days of acute abortive medication intake and, reduction of number of acute abortive medication tablets taken.

\section{RESULTS}

Majority of patients were aged between 31-45 years and were females in all the three groups. A higher proportion of patients had duration of migraine less than 10 years and had a positive family history of migraine (Table 1). The prevalence of migraine was found to be higher in the age group greater than 30 years approximately twice as compared to less than 30 years age group, females were effected about thrice as compared to males, duration of illness was upto 10 years in maximum subjects, family history was positive in majority of subjects (Table 1). Around $80 \%$ of the patients were non-vegetarian and details of the prior treatment indicated that $41(68 \%)$ patients were totally dependent on allopathic medicine; $30(50 \%)$ patients had tried both allopathic and alternative medicine such as Homeopathy, Unani/ Siddha, Ayurveda. It was found that exertion, lack of sleep and hunger were the three most important factors for aggravating migraine, at the time of enrollment all the patients reported more than six attacks in a year. Majority of patients of those who were enrolled had migraine attack once a week. Most complained of nausea, photo phobia, phono phobia, and vomiting as associated symptoms. A total of 60 patients were screened and relief in headache started to develop after 4 weeks and became conspicuous after 6weeks however patient fared much better, with better compliance less drop outs and minimal side effects in Group C.
Overall there was more reduction in CGI scores in flunarizine with panchgavya ghrit and the other two groups equally at the end of 4,68 and 10 weeks. However it was not statistically significant $(\mathrm{p}>0.05)$ (Table 2).

Decrease in MIDAS score was observed after the therapy. At the start of therapy most number of patients had Grade IV (severe disability)which came down to Grade II in group A and B and Grade I in group C inferring that little or no disability was observed in third group however mild disability was still present in Group I and II.

Table 1: Distribution of patients according to Sociodemographic variables.

\begin{tabular}{|c|c|c|c|c|c|c|}
\hline \multirow[t]{2}{*}{ Variables } & \multicolumn{2}{|c|}{$\begin{array}{l}\text { Flunarizine } \\
\text { group } \\
(\mathbf{n}=20)\end{array}$} & \multicolumn{2}{|c|}{$\begin{array}{l}\text { Flunarizine } \\
\text { and placebo } \\
\text { group } \\
(\mathrm{N}=20)\end{array}$} & \multicolumn{2}{|c|}{$\begin{array}{l}\text { Flunarizine } \\
\text { and } \\
\text { panchgavya } \\
\text { ghrit } \\
(\mathrm{N}=20)\end{array}$} \\
\hline & $\mathbf{N}$ & $\%$ & $\mathbf{N}$ & $\%$ & $\mathbf{N}$ & $\%$ \\
\hline \multicolumn{7}{|c|}{ Age (in yrs) } \\
\hline Upto 30 & 6 & 30 & 7 & 35 & 6 & 30 \\
\hline $31-45$ & 14 & 70 & 13 & 65 & 14 & 70 \\
\hline \multicolumn{7}{|l|}{ Gender } \\
\hline Male & 5 & 25 & 4 & 20 & 6 & 30 \\
\hline Female & 15 & 75 & 16 & 80 & 14 & 70 \\
\hline \multicolumn{7}{|c|}{ Duration of migraine } \\
\hline $0-10$ years & 10 & 50.0 & 11 & 55.0 & 12 & 60.0 \\
\hline $\begin{array}{l}11-20 \\
\text { years }\end{array}$ & 5 & 25.0 & 5 & 25.0 & 4 & 20.0 \\
\hline $\begin{array}{l}21-30 \\
\text { years }\end{array}$ & 5 & 25.0 & 4 & 20.0 & 4 & 20.0 \\
\hline \multicolumn{7}{|c|}{ Family history of migraine } \\
\hline Present & 14 & 70.0 & 15 & 75.0 & 14 & 70.0 \\
\hline Absent & 6 & 30.0 & 5 & 25.0 & 6 & 30.0 \\
\hline
\end{tabular}

Table 2: Change in CGI Score from Baseline among the patients.

\begin{tabular}{|c|c|c|c|c|c|c|c|c|c|c|c|}
\hline \multirow{2}{*}{\multicolumn{2}{|c|}{$\begin{array}{l}\text { Change from } \\
\text { baseline with } \\
\text { time }\end{array}$}} & \multicolumn{3}{|c|}{ Flunarizine $(\mathrm{n}=\mathbf{2 0})$} & \multicolumn{3}{|c|}{$\begin{array}{l}\text { Flunarizine with placebo } \\
(n=20)\end{array}$} & \multicolumn{3}{|c|}{$\begin{array}{l}\text { Flunarizine with } \\
\text { panchgavya ghrita }(n=20)\end{array}$} & \multirow{2}{*}{$\begin{array}{l}\text { chi } \\
\text { sq, p- } \\
\text { value }\end{array}$} \\
\hline & & Same & Decrease & Increase & Same & Decrease & Increase & Same & Decrease & Increase & \\
\hline \multirow{2}{*}{$\begin{array}{l}\text { After } 2 \\
\text { weeks }\end{array}$} & No. & 12 & 7 & 1 & 8 & 10 & 2 & 9 & 11 & - & \multirow{2}{*}{$\begin{array}{l}3.83, \\
0.430\end{array}$} \\
\hline & $\%$ & 60 & 35 & 5 & 40 & 50 & 10 & 45 & 55 & 0 & \\
\hline \multirow{2}{*}{$\begin{array}{l}\text { After } 4 \\
\text { weeks }\end{array}$} & No. & 10 & 9 & 1 & 7 & 12 & 1 & 7 & 13 & - & \multirow{2}{*}{$\begin{array}{l}2.51 \\
0.642\end{array}$} \\
\hline & $\%$ & 50 & 45 & 5 & 35 & 60 & 5 & 35 & 65 & 0 & \\
\hline \multirow{2}{*}{$\begin{array}{l}\text { After } 6 \\
\text { weeks }\end{array}$} & No. & 8 & 12 & -- & 7 & 13 & -- & 6 & 14 & -- & \multirow{2}{*}{$\begin{array}{l}0.440, \\
0.803\end{array}$} \\
\hline & $\%$ & 40 & 60 & 0 & 35 & 65 & 0 & 30 & 70 & 0 & \\
\hline \multirow{2}{*}{$\begin{array}{l}\text { After } 8 \\
\text { weeks }\end{array}$} & No. & 7 & 13 & -- & 7 & 13 & -- & 5 & 15 & -- & \multirow{2}{*}{$\begin{array}{l}0.616 \\
0.735\end{array}$} \\
\hline & $\%$ & 35 & 65 & 0 & 35 & 65 & 0 & 25 & 75 & 0 & \\
\hline \multirow{2}{*}{$\begin{array}{l}\text { After } \\
10 \\
\text { weeks }\end{array}$} & No. & 6 & 14 & -- & 6 & 14 & -- & 3 & 17 & -- & \multirow{2}{*}{$\begin{array}{l}1.37 \\
0.504\end{array}$} \\
\hline & $\%$ & 30 & 70 & 0 & 30 & 70 & 0 & 15 & 85 & 0 & \\
\hline
\end{tabular}


Table 3: Mean change in parameters pertaining to migraine scores from baseline in three groups.

\begin{tabular}{|c|c|c|c|c|c|c|c|c|c|}
\hline \multirow{2}{*}{ Parameter } & \multirow{2}{*}{ Group } & \multicolumn{8}{|l|}{ Day } \\
\hline & & 0 & 7 & 14 & 28 & 42 & 56 & 70 & 84 \\
\hline \multirow{3}{*}{ CGI } & Group 1 & 7 & & & & & & & \\
\hline & Group 2 & 7 & & & & & & & \\
\hline & Group 3 & 7 & & & & & & & \\
\hline \multirow{3}{*}{ CGI-I } & Group 1 & & 4 & 3 & 3 & 3 & 2 & 2 & 1 \\
\hline & Group 2 & & 4 & 3 & 3 & 2 & 2 & 1 & 1 \\
\hline & Group 3 & & 3 & 3 & 2 & 2 & 1 & 1 & 1 \\
\hline \multirow{3}{*}{ MIDAS } & Group 1 & 26 & & & & & & & 8 \\
\hline & Group 2 & 27 & & & & & & & 6 \\
\hline & Group 3 & 29 & & & & & & & 5 \\
\hline \multirow{3}{*}{ VAS } & Group 1 & 10 & 9 & 8 & 6 & 5 & 3 & 2 & 1 \\
\hline & Group 2 & 10 & 9 & 7 & 6 & 5 & 4 & 2 & 1 \\
\hline & Group 3 & 10 & 7 & 5 & 3 & 3 & 1 & 1 & 1 \\
\hline \multirow{3}{*}{ VRS } & Group 1 & Severe & Severe & Severe & Moderate & Moderate & Mild & Mild & Mild \\
\hline & Group 2 & Severe & Severe & Severe & Moderate & Moderate & Moderate & Mild & Mild \\
\hline & Group 3 & Severe & Severe & Moderate & Mild & Mild & Mild & Mild & Mild \\
\hline \multirow{3}{*}{ NPRS } & Group 1 & 8.33 & 7.33 & 7 & 6 & 5 & 3.33 & 2.33 & 1.33 \\
\hline & Group 2 & 8.66 & 8.33 & 7.66 & 6 & 5.33 & 4.33 & 2.33 & 1.33 \\
\hline & Group 3 & 9 & 7 & 5 & 3.33 & 2 & 1 & 1 & 0.66 \\
\hline
\end{tabular}

Table 4: Side effects assessed by DOTES.

\begin{tabular}{|c|c|c|c|c|c|c|c|c|c|c|c|c|c|c|c|c|c|c|c|c|c|}
\hline \multirow{2}{*}{$\begin{array}{l}\text { Side effects } \\
\text { assessed by } \\
\text { DOTES } \\
\text { Day }\end{array}$} & \multicolumn{7}{|c|}{ Group A (Flunarizine) } & \multicolumn{7}{|c|}{ Group B (Flunarizine with placebo) } & \multicolumn{7}{|c|}{$\begin{array}{l}\text { Group C (Flunarizine with } \\
\text { panchgavya ghrit) }\end{array}$} \\
\hline & 0 & $\Xi$ & $\infty$ & ร & $\stackrel{\circ}{n}$ & 우 & $\Phi$ & 0 & $\Xi$ & $\stackrel{\infty}{\sim}$ & ส & $\stackrel{\circ}{n}$ & 임 & $\Phi$ & 0 & $\Xi$ & $\stackrel{\sim}{\sim}$ & ร & 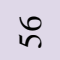 & \& & ১ \\
\hline \multicolumn{22}{|c|}{ a. Behavioural toxicity } \\
\hline Insomnia & - & 1 & 2 & 4 & 3 & 2 & 2 & - & 1 & 2 & 2 & 2 & 1 & 1 & 1 & 2 & 1 & 1 & - & - & - \\
\hline Drowsiness & - & 2 & 4 & 5 & 4 & 3 & 3 & - & 3 & 5 & 4 & 4 & 4 & 3 & 1 & 4 & 3 & 2 & 1 & - & \\
\hline \multicolumn{22}{|c|}{ b. Neurological } \\
\hline 1. Rigidity & - & 2 & 3 & 2 & 1 & 1 & 1 & - & 3 & 3 & 2 & 1 & 1 & - & - & 2 & 1 & - & - & - & - \\
\hline 2. Tremors & - & 3 & 3 & 2 & 2 & 1 & 1 & - & 3 & 3 & 2 & 1 & - & - & - & 1 & 1 & - & - & - & - \\
\hline \multicolumn{22}{|c|}{ c. A.N.S and G.I.T } \\
\hline 1. Dry mouth & - & 4 & 3 & 2 & 1 & - & - & - & 3 & 2 & 1 & 1 & - & - & - & 2 & 1 & - & - & - & - \\
\hline $\begin{array}{l}\text { 2. Blurred } \\
\text { vision }\end{array}$ & - & - & 1 & 2 & - & - & - & - & - & 2 & 1 & - & - & - & - & - & - & - & - & - & - \\
\hline $\begin{array}{l}3 . \\
\text { Constipation }\end{array}$ & - & 3 & 2 & 2 & 1 & - & - & - & - & 2 & 1 & 1 & - & - & - & - & - & - & - & - & - \\
\hline 4. Nausea & - & 2 & 4 & 6 & 4 & 2 & 2 & - & 2 & 3 & 4 & 3 & 3 & 2 & - & 4 & 3 & 3 & 2 & 1 & - \\
\hline 5. Diarrhoea & - & 1 & 2 & 2 & - & - & - & - & 1 & 2 & 2 & - & - & - & - & 3 & 2 & 2 & 1 & - & - \\
\hline \multicolumn{22}{|l|}{ d. Others } \\
\hline 1. & & & & & & & & & & & & & & & & & & & & & \\
\hline $\begin{array}{l}\text { Dermatologic } \\
\text { (RASH) }\end{array}$ & - & 2 & 2 & 1 & - & - & - & - & 2 & 1 & 1 & - & - & - & - & 1 & - & - & - & - & - \\
\hline $\begin{array}{l}\text { 2. Weight } \\
\text { gain }\end{array}$ & - & - & 3 & 3 & 2 & 2 & 1 & - & 3 & 3 & 2 & 2 & 2 & 2 & - & 2 & 2 & 1 & - & - & - \\
\hline
\end{tabular}

Clinical Global Impression rating scale employed revealed that to start with subjects scored 7 which stands for pathology interfering in many life functions which reduced drastically in Group C as compared to Group B and Group A in descending order. The implications were that there were rapid rate of recovery in clinical status of Group C as compared to other two groups. Pain scales namely VAS (visual analogue scale), NPRS (Numeric Pain Rating Scale), VRS (verbal rating scale) when employed denoted there was decreased migraine 
frequency, decreased perception of pain, less intake of abortive medication consumed by subjects implying there were reduction in number of migraine days and there was decrease in the abortive medications taken for the same. Group C scored better on pain scales followed by Group B and Group A (Table 3).

Table 5: Side effect and symptoms associated with migraine reported by the patient, observed by the clinician or elicited by the therapist.

\begin{tabular}{|c|c|c|c|c|c|c|c|c|c|c|c|c|c|c|c|c|c|c|c|c|c|}
\hline \multirow{2}{*}{$\begin{array}{l}\text { Side effects } \\
\text { reported } \\
\text { DAYS }\end{array}$} & \multicolumn{7}{|c|}{ Group A } & \multicolumn{7}{|c|}{ Group B } & \multicolumn{7}{|c|}{ Group C } \\
\hline & $\mathbf{0}$ & 14 & 28 & 42 & 56 & 70 & 84 & $\mathbf{0}$ & 14 & 28 & 42 & 56 & 70 & 84 & 0 & 14 & 28 & 42 & 56 & 70 & 84 \\
\hline Anxiety & - & 2 & 2 & 1 & - & - & - & - & 2 & 1 & 1 & - & - & - & - & - & - & - & - & - & - \\
\hline Depression & - & 2 & 1 & - & - & - & - & - & 2 & 1 & - & - & - & - & - & - & - & - & - & - & - \\
\hline Dizziness & - & 1 & 1 & - & - & - & - & - & - & - & - & - & & & & & & & & & \\
\hline Sedation & - & 2 & 1 & 1 & - & - & - & - & 2 & 2 & 1 & - & - & - & - & 1 & - & - & - & -- & - \\
\hline Fatigue & - & 2 & 1 & - & - & - & - & - & 2 & 1 & - & - & - & - & - & - & - & - & - & -- & - \\
\hline Vertigo & - & 3 & 2 & 1 & - & - & - & - & 2 & 2 & 1 & - & - & - & - & - & - & - & - & -- & - \\
\hline Headache & - & & 1 & - & - & - & - & - & 2 & 1 & - & - & - & - & - & - & - & - & - & -- & - \\
\hline $\begin{array}{l}\text { Increased } \\
\text { appetite }\end{array}$ & - & & 2 & - & - & - & - & - & 3 & 2 & - & - & - & - & - & - & - & - & - & -- & - \\
\hline Epigastric pain & - & 2 & 1 & - & - & - & - & - & 1 & - & - & - & - & - & - & - & - & - & - & -- & - \\
\hline Heart burn & - & 3 & 3 & 2 & - & - & - & - & 3 & 3 & 2 & 1 & - & - & - & - & - & - & - & -- & - \\
\hline Vomiting & - & 2 & 1 & - & - & - & - & - & 2 & 1 & - & - & - & - & - & - & - & - & - & -- & - \\
\hline Muscle ache & - & 2 & 1 & - & - & - & - & - & 2 & 1 & - & - & - & - & - & - & - & - & - & -- & - \\
\hline $\begin{array}{l}\text { Menstrual } \\
\text { iregularity }\end{array}$ & - & 3 & 3 & 2 & 2 & - & - & - & 2 & 2 & 1 & - & - & - & - & - & - & - & - & -- & - \\
\hline Photophobia & - & 5 & 4 & 3 & 2 & 1 & - & - & 4 & 3 & 3 & 2 & 1 & - & - & 3 & 2 & 1 & - & -- & - \\
\hline Phonophobia & - & 4 & 3 & 1 & - & - & - & - & 4 & 3 & 2 & 1 & - & - & - & 3 & 2 & 1 & - & - & - \\
\hline
\end{tabular}

Lower proportion of individuals in group $\mathrm{C}$ had Behavioural Toxicity and Neurological Side effects as compared to Group A and B (Table 4). Lower number of patients reported side effects associated with migraine in group $\mathrm{C}$ as compared to group $\mathrm{A}$ and $\mathrm{B}$ (Table 5).

\section{DISCUSSION}

Since the pharmaceutical treatment of migraine is complex, with no agreed upon guidelines individuals often need abortive medication during acute attacks and some prophylactic measure to reduce attacks. Some abortive drugs such as Triptans and ergotamine tartrate are often expensive and not commonly used in resourcepoor countries, resulting in a significant amount of pain and disability. ${ }^{22}$ Another problem is the actual overuse of such medications which causes 'medication overuse headache' (MOH), further complicating management strategies. $^{23}$

A large percentage of patients do not respond to pharmacological interventions for migraine headache, develop unacceptable side-effects, or are reluctant to take medications. ${ }^{24}$ As a result many patients resort to many complementary and alternative therapies like acupuncture, biofeedback therapy, relaxation therapy, herbal remedies and vitamin or mineral supplementation. ${ }^{24-26}$ Recent studies have demonstrated the effectiveness of acupuncture and Yoga in the reduction of migraine headache. The use of complementary and alternative medicine (CAM) in migraine is a growing phenomenon which, though increasingly widespread, is poorly understood. ${ }^{27-29}$ Ayurveda is a traditional medical system used by a majority of India's 1.1 billion population. ${ }^{30}$ Though Ayurvedic therapy is popular among migraine sufferers, there are very few studies which have compared pharmacotherapy pertaining to combination of two lines of treatment aiming for the holistic view of treatment with aim of increasing compliance, increasing potency of drugs and reducing side effects caused by allopathic medicines when administered alone. Migraine was distinguished from common headache by Tissot in 1783 for the first time who ascribed it to a supra-orbital neuralgia provoked by reflexes from the stomach, gall bladder or uterus. Later, migraine was classified as a neurological disorder. Our hypothesis is quite similar to Tissot's idea on the pathogenesis of migraine, viz. that it usually arose from stomach disturbance. ${ }^{31}$ Incidentally, there is a close correlation between the symptoms of migraine with those of Amla-pitta (state of acid-alkali imbalance in the body) causing symptoms such as: brahma(confusion), moorcha (fainting), aruchi (anorexia), aalasya (fatigue), chardi (vomiting), prasek (nausea), mukhmadhurya (sweetness in the mouth) and shiroruja (headache). The correlation between the cause and symptoms of Amla-pitta match the current diagnosis criteria of migraine. 
Complimentary and Alternative Medicine (CAM) is often perceived by the public to be more helpful than conventional care for the treatment of headache. ${ }^{32}$ This study is also in line with the prior ayurvedic researchers which stress upon effectiveness safety and tolerability of ayurvedic medications in migraine prophylaxis. ${ }^{33}$ This study is first of its kind as we could not find any previous study from literature search reporting a comparision between the efficacy of flunarizine, flunarizine and placebo and flunarizine and panchgavya ghrit in migraine prophylaxis. The non-cross-over design had subjects having migraine without aura, although less powerful than the cross-over design, had the advantage of avoiding the carryover effect, a feature of great importance in migraine prophylaxis trials. From this comparative study we can make a preliminary assessment that combination of standard prophylaxis in allopathic medication along with panch gavya ghrit caused decrease in measures of symptom severity, better tolerability, lesser side effects, better compliance, lesser drop outs, good treatment response and efficacy among patients with migraine, implying that panch gavya ghrit when administered along with flunarizine was more efficacious and safe when compared with other two groups. However large multicentric RCTs of long duration and involving more number of subjects are required to ascertain these facts.

Funding: No funding sources

Conflict of interest: None declared

Ethical approval: The study was approved by the Institutional Ethics Committee

\section{REFERENCES}

1. Lantéri-Minet $\mathrm{M}$. The role of general practitioner in migraine management. Cephalalgia. 2008;28:1-8.

2. Vijayan S. Migraine: An expensive headache to the world. Available from: http://thelancetstudent.com/2008/03/16/ migraine-anexpensive-headache-to-the-globe/.

3. Ravishankar K. Barriers to headache care in India and effort to improve the situation. Lancet Neurol. 2004;3:564-7.

4. Lipton RB, Diamond S, Reed M, Diamond ML, Stewart WF. Migraine diagnosis and treatment: results from the American Migraine Study II. Headache. 2001;41:638-45.

5. Lipton RB, Stewart WF, Diamond S, Diamond ML, Reed M. Prevalence and burden of migraine in the United States: data from the American Migraine Study II. Headache. 2001;41:646-57.

6. Ramadan NM, Silberstein SD, Freitag FG, Gilbert TT, Frishberg BM. Evidence-based guidelines for migraine headache in the primary care setting: pharmacological management for prevention of migraine; 2005. Available at: http://www.aan.com/professionals/practice/guideline.

7. Bhavamisra, Bhavaprakasa, KR Srikantamoorthy, Krishnadas Academy Varanasi. 2000;33:306.
8. Agnivesa, Carakasamhita- Chikitsasthana 10/20, with the commentary of Cakrapanidatta- Varanasi Krishnadas academy, 2009;307.

9. Tiwari PV, Kasyapa Samhitha $2^{\text {nd }} E d$, Chawkamba Viswabharati Varanasi. 2002;243.

10. Nighantu B, Srikantha Murthy RS. Krishnadas Academy, Varanasi, $1^{\text {st }}$ Ed; 1998:470.

11. Nighantu B, Srikantha Murthy RS. Krishnadas Academy, Varanasi, $1^{\text {st }}$ Ed; 1998:454.

12. Nighantu B, Srikantha Murthy RS. Krishnadas Academy, Varanasi, $1^{\text {st }}$ Ed; 1998:473.

13. Panchagavya Ayurved Chikitsa, Ed. and Pub. by Gau-Vigyan Anusandhan Kendra, Devlapur-Nagpur, $3^{\text {rd }} \mathrm{Ed} ; 2006: 7: 62$.

14. Curds benefits, Side effects as per Ayurveda. Available from: Easyayurveda.com/2010/12/31/curds-benefits Last accessed 23-03-2017.

15. Koneru A. Journal of Pharmacy Research, Anticonvulsant Activity of Panchagavya Ghrita: a Poly-Herbal Ayurvedic formulation. 2009;2(5):7957.

16. Achalia GS, Kotagle NR, Wadodkar SG, Dorle AK. Hepatoprotective activity of Panchagavya Ghrita against Carbontetrachloride induced Hepatotoxicity in rats, Indian Journal of Pharmacology. 2003;35:308-311.

17. Pawar A. Experimental evaluation of anti epileptic activity of Panchagavya Ghrita (PGG) and its effect on memory, 2013.

18. Diamond S, Kudrow L, Stevens J, Shapiro BD. Long-term study of propranolol in the treatment of migraine. Headache. 1982;22:268-71.

19. Martínez-Lage JM. Flunarizine (Sibelium) in the prophylaxis of migraine: an open, long-term, multicenter trial. Cephalalgia. 1988;8(8):15-20.

20. Sorensen PS, Hansen K, Olesen J. A placebocontrolled, double-blind, cross-over trial of flunarizine in common migraine. Cephalalgia. 1986;6:7-14.

21. Tfelt-Hansen P, Standnes B, Kangasneimi P, Hakkarainen H, Olesen J. Timolol versus propranolol versus placebo in common migraine prophylaxis: A double-blind multicenter trial. Acta Neurol Scand. 1984;69:1-8.

22. Neurological Disorders: Public health challenges. World Health Organization. 2006. Available at ogy/neurological_disorders_report_web.pdf Last accessed 23-03-2017.

23. Limmroth V, Kazarawa Z, Fritsche G, Diener HC. Headache after frequent use of serotonin agonists zolmitriptan and naratriptan. 1999;353:78.

24. Mauskop A. Complementary and alternative treatments for migraine. Drug Dev Res. 2008;68:4247.

25. Witt CM, Reinhold T, Jena S, Brinkhaus B, Willich SN. Cephalalgia. 2008;28:334-45.

26. Nestoriuc Y, Martin A, Rief W, Andrasik F. Biofeedback treatment for headache disorders: A 
comprehensive efficacy review. Appl Psychophysiol Biofeedback. 2008;33:125-40.

27. Facco E, Liguori A, Petti F, Zanette G, Coluzzi F, De Nardin M, et al. Traditional acupuncture in migraine: A controlled, randomized study. Headache. 2008;48:398-407.

28. John PJ, Sharma N, Sharma CM, Kankane A. Effectiveness of yoga therapy in the treatment of migraine without aura: A randomized controlled trial. Headache. 2007;47:654-61.

29. Rossi P, Di Lorenzo G, Malpezzi MG, Faroni J, Cesarino F, Di Lorenzo C, et al. Prevalence, pattern and predictors of use of complementary and alternative medicine (CAM) in migraine patients attending a headache clinic in Italy. Cephalalgia. 2005;25:493-506.
30. Gogtay NJ, Bhatt HA, Dalvi SS, Kshirsagar NA. The use and safety of non-allopathic Indian medicines. Drug Saf. 2002;25:1005-19.

31. Eadie MJ. An 18th century understanding of migraine - Samuel Tissot (1728-1797) J Clin Neurosci. 2003;10:414-9.

32. MacLennan AH, Wii DH, Taylor AW. Prevalence and cost of alternative medicine in Australia. 1996:347569-73.

33. Vaidya PB, Vaidya BS, Vaidya SK. Response to Ayurvedic therapy in the treatment of migraine without aura Int J Ayurveda Res. 2010;1(1):30-6.

Cite this article as: Trivedi M, Dixit V, Mahmood SE, Mishra SK, Keshari SS. Efficacy and safety of panchgavya GHRIT along with flunarizine in prophylaxis for migraine patients: a comparitive study. Int J Basic Clin Pharmacol 2017;6:948-54. 